\title{
MENINGKATKAN HASIL BELAJAR SISWA PADA PEMBELAJARAN MATEMATIKA DENGAN MENERAPKAN TEORI BELAJAR BRUNER
}

\author{
BERNADETA RITAWATI \\ Program Studi Pendidikan Matematika STKIP Pamane Talino, \\ $J l$ Afandi Rani Jalur 2 Ngabang Kalimantan Barat \\ bernadetha.pamane@gmail.com
}

First Received: 16-07-2019; Accepted: 22-10-2019

\begin{abstract}
Abstrak
Penelitian ini bertujuan untuk meningkatkan hasil belajar siswa dengan menerapkan teori belajar Bruner. Penelitian ini merupakan penelitian tindakan kelas. Penelitian ini dilaksanakan di SMPN 2 Ngabang. Subjek penelitian ini adalah siswa kelas 7 semester II tahun pelajaran 2018/2019 yang terdiri dari 41 siswa. Objek penelitian ini adalah pembelajaran matematika. Penelitian ini menghasilkan: 1) Proses pembelajaran matematika yang membosankan membuat siswa jenuh karena metode, media dan model yang digunakan guru tidak dapat menarik minat dan perhatian siswa sehingga siswa tidak bisa fokus dan pasif ketika berinteraksi dengan guru. 2) Pembelajaran matematika secara esensial belajar mengenai hubungan antara konsep matematika, yang membuat siswa mudah untuk memahami subjek matematika. 3) Aktivitas siswa dilakukan dalam 3 tahap: enaktif, ikonik, dan simbolik membuat siswa aktif. 4) Dengan aktivitas, siswa dapat dengan mudah menemukan jawaban dari pertanyaan apa, bagaimana, dan mengapa khususnya siswa dapat memahami mengenai materi yang dipelajari.
\end{abstract}

Kata kunci: Teori Bruner; Matematika; Hasil belajar.

\section{IMPROVING STUDENT'S LEARNING OUTCOMES IN MATHEMATICS LEARNING BY APPLYING BRUNER'S THEORY}

\begin{abstract}
This study aims to improve students' learning outcomes in mathematics learning by applying Bruner's theory. This research is a classroom action research. The study was conducted at SMPN 2 Ngabang. The subjects were seventh grades students in semester II 2018/2019 academic year which consists of 41 students. The object of this research is mathematics learning. This study concludes that: 1) The process of learning mathematics is boring which makes students bored because the methods, media and models that the teacher uses cannot attract students' interest and attention so students can't be focused and passive in interacting with the teacher. 2) Learning mathematics is essentially learning about the relationship between concepts in mathematical material, thus making students easy to understand the subject materials. 3) Activities that students do in 3 stages; active, iconic, and symbolic make students active. 4) With activities, students can easily find out the answers of what, how, and why in a case, especially students can understand about the material which is being studied easily.
\end{abstract}

Keywords: Bruner's theory; Mathematics; Learning outcomes. 


\section{PENDAHULUAN}

Matematika menjadi alat bagi manusia untuk bepikir logis. Namun tak jarang, dalam pembelajaran di bangku pendidikan, pelajaran matematika masih dianggap sulit dan kurang disukai oleh siswa. Hudojo (Hasatuddin, 2014, p.30) menyatakan bahwa matematika merupakan ide-ide abstrak yang diberi simbol-simbol itu tersusun secara hirarkis dan penalarannya deduktif, sehingga belajar matematika itu merupakan kegiatan mental yang tinggi. Menurut Bruner belajar matematika adalah belajar tentang konsep-konsep dan struktur-struktur matematika yang terdapat di dalam materi yang dipelajari, serta mencari hubungan antara konsep-konsep dan stuktur-struktur matematika itu. Jika dalam pembelajaran matematika siswa memahami konsep, maka materi pembelajaran akan mudah dipahami dan hasil belajar siswa semakin meningkat sehingga tujuan pembelajaran yang ingin dicapai bisa terealisasi. Akan tetapi, kenyataan yang terjadi di SMP Negeri 2 Ngabang khususnya dalam pembelajaran matematika masih banyak siswa yang belum aktif dan belum memahami konsep dari materi yang peneliti sampaikan. Hal ini bisa dilihat pada saat mengikuti kegiatan pembelajaran matematika, masih banyak siswa yang kurang bersemangat dan cenderung pasif di kelas, diam dan kurang antusias.

Pembelajaran matematika kelas VII di SMP Negeri 2 Ngabang, ditemui siswa kurang aktif dalam proses pembelajaran. Kurang aktif yang peneliti maksud adalah siswa kurang aktif melakukan kegiatan-kegiatan yang guru berikan, kurang berusaha, kurang bertanya atau menjawab, tidak memperhatikan guru, sibuk sendiri, sulit mengungkapkan pemikiran dan sebagainya. Hal ini berpengaruh sangat besar sekali pada prestasi dan hasil belajar siswa yang tidak maksimal terutama pada hasil ulangan harian, latihan, tugas, dan UAS. Jumlah siswa kelas VII adalah 41 orang.

Berdasarkan data awal nilai siswa melalui UAS terdapat $64 \%$ siswa yang belum mencapai standar atau KKM 60 di sekolah pada mata pelajaran matematika tersebut. Sedangkan nilai siswa yang memenuhi standar 15 orang, hanya 36\%. Permasalahan yang terjadi ini biasanya dapat terjadi karena dua pengaruh, yaitu pengaruh internal dan eksternal.

Pengaruh internal biasa timbul dari dalam diri siswa yang dipengaruhi oleh kemalasan, tidak menyenangi matematika, tidak paham, dan sebagainya. Sedangkan, pengaruh eksternal dari lingkungan sekitar, sarana, sumber, guru, metode, dan sebagainya yang mengakibatkan siswa tidak aktif dalam belajar.

Selama ini juga mata pelajaran matematika tidak disenangi oleh sekian banyak siswa, karena selalu dianggap sebagai mata pelajaran yang sangat sulit untuk dipahami, 
membosankan, monoton, dan membuat pusing. Mata pelajaran matematika juga dianggap hanya mudah dipahami, dipelajari, dan dikerjakan oleh orang-orang yang intelektual tinggi. sehingga banyak siswa yang tidak menyenanginya.

Kurang aktif siswa dalam belajar bisa saja terjadi karena kurang sesuai dengan kebutuhan, karakter siswa, cara yang mungkin membosankan. Sesungguhnya mata pelajaran matematika merupakan pelajaran yang sangat penting untuk dipelajari juga layaknya pelajaran yang lain-lainnya. Karena, mata pelajaran ini tetap dipelajari dari pendidikan tingkat dasar sampai perguruan tinggi.

Matematika merupakan pelajaran yang benar-benar dapat membuat siswa mampu berpikir kritis, kreatif, melatih ketelitian, dan selalu dijumpai dalam kehidupan sehari-hari. Tetapi, peneliti melihat hal itu terjadi sebaliknya. Justru siswa tidak menyenangi pelajaran matematika. Hal ini yang mengakibatkan siswa kurang aktif dalam belajar, hanya asal-asalan saja. Sehingga mempengaruhi hasil dan tujuan dari pembelajaran yang sudah ditetapkan.

Tujuan kegiatan pembelajaran yang utama yang dilakukan oleh pendidik adalah agar dapat mencapai hasil yang maksimal dan prestasi siswa yang baik. Karena, subjeknya adalah siswa, dan subjek produk utama dalam pembelajaran adalah hasil yang siswa peroleh. Terutama objek-objek yang dilakukan oleh pendidik yang harus disesuaikan dengan karakteristik siswa, kebutuhan siswa, dan materi pelajaran.

Objek-objek itu bisa saja berupa metode-metode yang digunakan, kegiatan-kegiatan siswa, kemampuan siswa dalam proses pembelajaran. Hal ini sangat besar sekali dalam mempengaruhi kegiatan pembelajaran siswa, karena siswa yang dituntut untuk terlibat serta berperan langsung dalam pembelajaran.

Dengan siswa ikut terlibat, dan melakukan secara langsung apa yang dipelajari secara otomatis siswa mudah menerima, memahami setiap materi yang diajarkan oleh guru. Karena pada dasarnya jika dengan kegiatan menyimak, melakukan, dan mempraktikkan apa yang disampaikan lebih mudah untuk dipahami, dibandingkan hanya mendengarkan penjelasan saja tanpa secara langsung dilakukan oleh siswa itu sendiri.

Penulis akan menggunakan 3 tahap teori Bruner, yaitu: enaktif, ikonik, dan simbolik, serta menggunakan teori Piaget melalui 4 tahap, yaitu: tahap konkret, semi konkret, semi abstrak, abstrak.

Dalam penelitian ini akan dilakukan penerapan pembelajaran matematika yang multi representasi yang diharapkan dapat meningkatkan keaktivan siswa dalam mengikuti proses pembelajaran, sehingga tujuan pembelajaran dapat dicapai sesuai dengan tujuan yang telah ditetapkan. 


\section{METODE PENELITIAN}

Penelitian ini dilaksanakan dalam suatu siklus yang terdiri dari beberapa tahap, yaitu rencana, penelitian, pelaksanaan, evaluasi, dan refleksi. Siklus yang dilaksanakan maksimal tiga siklus, yaitu siklus I, siklus II, dan siklus III. Setiap siklus dilaksanakan dalam dua kali pertemuan. Tetapi, jika pelaksanaan pada siklus I belum mencapai kriteria keberhasilan akan dilanjutkan siklus II, dan seterusnya. Beberapa siklus yang dilakukan untuk mengetahui keberhasilan pada penelitian yang akan dilaksanakan dalam penelitian ini. Dalam penelitian ini yang menjadi subjek penelitian adalah siswa kelas VII, semester II di SMP Negeri 02 Ngabang, Kabupaten Landak. Siswa berjumlah 42 orang yang telah keluar 1 orang, menjadi 41 orang. Peneliti memilih kelas VII sebagai subjek penelitian, karena peneliti melihat bahwa siswa kelas VII kurang aktif dalam pembelajaran matematika. Sedangkan, sebagai objek penelitian ini adalah aktivitas siswa, kemampuan berpikir kritis siswa, tanggapan siswa, dan usaha siswa dalam proses pembelajaran yang dilaksanakan.

Dalam penelitian ini telah dilasanakan 2 siklus dengan empat kali pertemuan, untuk mengetahui keberhasilan dalam penelitian ini, sebagai berikut:

\section{Siklus I}

Dalam penelitian ini telah dilaksanakan dalam dua kali pertemuan, yang telah diikuti oleh 35 siswa kelas VII SMP Negeri 02 Ngabang dari jumlah seluruhnya adalah 41 orang.

\section{Pertemuan I}

Rencana penelitian: 1) Membuat rancangan pembelajaran dengan metode pembelajaran yang multi representasi. 2) Menyiapkan sumber belajar sesuai dengan materi pelajaran berupa buku pelajaran dan alat tulis. 3) Menyiapkan media pembelajaran berupa benda-benda konkret: a) Menyiapkan bentuk-bentuk tugas untuk siswa b) Menyiapkan beberapa pertanyaan untuk siswa.

Pelaksanaan tindakan: pada tahap ini peneliti membuat Rencana Pelaksanaan Pembelajaran (RPP), yang digunakan pada pelaksanaan pembelajaran dengan menerapkan multi representasi di kelas sebagai upaya dalam mengaktifkan siswa.

Adapun kriteria yang digunakan pada pembelajaran matematika yang multi representasi adalah sebagai berikut: 1) Metode, model dan sarana yang digunakan berbeda. 2) Disenangi dan mudah diterima oleh siswa sesuai materi pelajaran. 3) Mempunyai daya kreativitas untuk membimbing siswa. 4) Pembelajaran yang dapat menumbuhkan aktivitas siswa. 
Pada penelitian ini data-data yang diperoleh, secara deskriptif akan dianalisis dan disajikan dalam bentuk tabel dan diagram. Data-data yang akan dianalisis tujuannya untuk mengetahui adanya perubahan atau perbaikan proses, meningkat atau tidak aktivitas siswa dalam proses pembelajaran matematika.

Data-data yang diperoleh berdasarkan hasil observasi yang dilakukan dalam kegiatan siswa selama mengikuti pembelajaran dalam 3 tahap, yaitu: tahap enaktif, tahap ikonik, dan tahap simbolik. Kriteria keberhasilan dapat diperoleh dari rata-rata persentase 3 tahap tersebut. Kriteria keberhasilan adalah 78,00\%.

Pada penelitian ini tujuan utama adalah meningkatkan aktivitas siswa dalam mengikuti pembelajaran, yang bertujuan dapat mempengaruhi hasil belajar, dan prestasi siswa yang lebih baik. Karena, kriteria keberhasilan hasil belajar siswa berdasarkan Kriteria Ketuntasan Minimal (KKM) SMP Negeri 02 Ngabang yaitu 60.

\section{HASIL DAN PEMBAHASAN}

Desain yang digunakan dalam penelitian ini terdiri atas dua siklus yang meliputi siklus I dan siklus II. Setiap siklus pada penelitian ini meliputi tiga tahapan, yaitu: (1) perencanaan, (2) pelaksanaan dan observasi, (3) refleksi. Hasil evaluasi dari aktivitas belajar yang didapat dari setiap tindakan pada dua siklus yang telah dilaksanakan adalah sebagai berikut:

Tabel 1. Hasil aktivitas siswa siklus I dan siklus II

\begin{tabular}{cccc}
\hline No & Siklus & Aktivitas siswa & Persentase \\
\hline 1. & I & Tahap enaktif, tahap ikonik, dan tahap simbolik. & $\mathbf{7 0 , 1 3 \%}$ \\
2. & II & Tahap enaktif, tahap ikonik, dan tahap simbolik. & $\mathbf{8 0 , 2 5 \%}$ \\
\hline
\end{tabular}

Hasil yang terdapat pada tabel di atas diperoleh dari rerata beberapa kriteria-kriteria penilaian yang peneliti rumuskan dalam penelitian ini. Dari data pada tabel di atas dapat diketahui bahwa aktivitas siswa dalam proses pembelajaran terjadi peningkatan. Peningkatan ini dapat dilihat pada siklus I hanya mencapai 70,13\% dan siklus II meningkat menjadi $80,25 \%$.

Dengan adanya peningkatan aktivitas siswa dalam proses pembelajaran terjadi pengaruh pada hasil belajar siswa juga meningkat yang diketahui pada hasil evaluasi belajar. 


\section{Hasil Tindakan}

Hasil tindakan yang diperoleh pada penelitian ini dapat dilihat pada dua siklus yang telah dilakukan.

\section{Hasil Tindakan Siklus I}

1. Perencanaan

Pada tahap perencanaan ini, peneliti membuat RPP yang dilaksanakan dengan menerapkan multi representasi di kelas. Peneliti juga menentukan aspek-aspek penilaian aktivitas siswa, lembar observasi, alat evaluasi hasil belajar, dan membuat evaluasi proses yang akan dilakukan oleh observer. Selain itu juga peneliti mempersiapkan benda konkret berbentuk kubus dan balok yang ada di lingkungan sekitar.

2. Pelaksanaan

Langkah-langkah yang dilakukan dalam tahap pelaksanaan pada penelitian ini adalah sebagai berikut: 1) Memberi penjelasan tentang metode yang akan digunakan, serta membagi siswa menjadi 7 kelompok. 2) Memperlihatkan benda-benda yang konkret yang berbentuk kubus dan balok, misalnya: kotak pepsodent, kotak bola lampu, kotak senter, dll. 3) Setiap siswa menyebutkan, menunjukkan, dan menggambar bagian-bagian kubus dan balok. Siswa juga menuliskan jumlah jaring-jaring kubus dan balok berupa angka. 4) Setiap kelompok menggunting benda-benda konkret untuk memperoleh jaring-jaring kubus atau balok, dan mempresentasikan ke depan kelas. 5) Siswa menyelesaikan lembar kerja. 6) Guru melakukan observasi apakah proses pembelajaran yang dilaksanakan sudah sesuai dengan yang perencanaan dalam RPP, bersama observer. Observasi yang dilakukan adalah mengamati: (a) Aktivitas siswa, (b) Sesuai atau tidak penerapan multi representasi, (c) kemampuan guru dalam mengelola kelas, serta memanfaatkan bendabenda konkret, (d) kemampuan siswa dalam mengerjakan lembar kerja.

Proses pembelajaran pada siklus I dilaksanakan tanggal 15 Mei dan 17 Mei tidak sesuai dengan rencana. Siswa yang hadir hanya 35 orang dari jumlah seluruh siswa adalah 41 yang semula jumlah siswa adalah 42 siswa. Berkurang karena 1 orang sudah tidak sekolah lagi.

Tabel 2. Hasil observasi aktivitas siswa siklus I

\begin{tabular}{|c|c|c|c|c|c|c|c|c|c|c|c|c|c|c|c|}
\hline \multicolumn{16}{|c|}{ Aktivitas Siswa } \\
\hline \multirow[t]{2}{*}{ No. } & \multirow[t]{2}{*}{$\begin{array}{l}\text { Kode } \\
\text { Siswa }\end{array}$} & \multicolumn{4}{|c|}{$\begin{array}{c}\text { Tahap } \\
\text { Enaktif }\end{array}$} & \multicolumn{3}{|c|}{$\begin{array}{l}\text { Tahap } \\
\text { Ikonik }\end{array}$} & \multicolumn{4}{|c|}{$\begin{array}{c}\text { Tahap } \\
\text { Simbolik }\end{array}$} & \multirow{2}{*}{\multicolumn{2}{|c|}{$\begin{array}{c}\text { Jum Skor } \\
\text { lah ideal }\end{array}$}} & $\%$ \\
\hline & & 1 & 2 & 3 & 4 & 1 & 2 & 3 & 4 & 1 & 2 & 3 & & & \\
\hline 1 & As & & & & & & & & & & & & & 6 & 50,0 \\
\hline
\end{tabular}


RIEMANN Volume 1, No. 1, Oktober 2019, hal. 25-36

\begin{tabular}{|c|c|c|c|}
\hline 2 & $\mathrm{AI}$ & 11 & 91,6 \\
\hline 3 & $\mathrm{Am}$ & & \\
\hline 4 & $\mathrm{Ad}$ & 8 & 66,6 \\
\hline 5 & $\mathrm{Aa}$ & 6 & 50,0 \\
\hline 6 & APP & 8 & 66,6 \\
\hline 7 & $\mathrm{Aw}$ & 9 & 75,0 \\
\hline 8 & Aeu & 8 & 66,6 \\
\hline 9 & $\mathrm{Br}$ & 8 & 66,6 \\
\hline 10 & $\mathrm{Bf}$ & 6 & 50,0 \\
\hline 11 & $\mathrm{Cp}$ & 11 & 91,6 \\
\hline 12 & $\mathrm{Dw}$ & & \\
\hline 13 & $\mathrm{DA}$ & 11 & 91,6 \\
\hline 14 & DDn & 10 & 83,3 \\
\hline 15 & DRS & 11 & 91,6 \\
\hline 16 & EEr & 9 & 75,0 \\
\hline 17 & $\mathrm{Er}$ & 9 & 75,0 \\
\hline 18 & GhP & 10 & 83,3 \\
\hline 19 & $\mathrm{HH}$ & 6 & 50,0 \\
\hline 20 & HD & 7 & 58,3 \\
\hline 21 & IP & 11 & 91,6 \\
\hline 22 & Ks & & \\
\hline 23 & $\mathrm{Ln}$ & 7 & 58,3 \\
\hline 24 & Ml & 7 & 58,3 \\
\hline 25 & ORp & 11 & 91,6 \\
\hline 26 & OD & 6 & 50,0 \\
\hline 27 & Pcc & 7 & 58,3 \\
\hline 28 & $\mathrm{RP}$ & 11 & 91,6 \\
\hline 29 & RPS & 8 & 66,6 \\
\hline 30 & $\mathrm{Sr}$ & 9 & 75,0 \\
\hline 31 & SA & & \\
\hline 32 & SW & & \\
\hline 33 & SI & 5 & 41,6 \\
\hline 34 & $\mathrm{St}$ & 10 & 83,3 \\
\hline 35 & $\mathrm{Vy}$ & 7 & 58,3 \\
\hline 36 & VI & 6 & 50,0 \\
\hline 37 & WA & 8 & 66,6 \\
\hline 38 & WSs & 8 & 66,6 \\
\hline 39 & YD & & \\
\hline 40 & $\mathrm{YN}$ & 7 & 58,3 \\
\hline 41 & $\mathrm{Yw}$ & 7 & 58,3 \\
\hline
\end{tabular}

Keterangan:

a. Tahap Enaktif, yaitu:

1. Menyebut benda berbentuk kubus dan balok.

2. Menyebut bentuk benda konkret.

3. Menyebut bagian-bagian benda konkret.

4. Menunjuk jaring-jaring benda konkret. 
b. Tahap Ikonik, yaitu:

1. Menggambar benda konkret.

2. Menggambar benda berbentuk kubus dan balok.

3. Menggambar bentuk jaring-jaring kubus dan balok.

4. Menggambar susunan jaring-jaring kubus dan balok.

c. Tahap Simbolik, yaitu:

1. Menyebut jumlah benda berbentuk kubus dan balok.

2. Menghitung benda berbentuk kubus dan balok.

3. Menghitung jumlah jaring-jaring kubus dan balok.

4. Menulis jumlah jaring-jaring kubus dan balok.

Dari proses pembelajaran siklus I pada pertemuan pertama dan pertemuan kedua yang telah dilaksanakan dengan jumlah siswa yang hadir hanya 35 dan 40 orang, dari 41 orang siswa telah diperoleh hasil siswa yang aktif dalam proses pembelajaran hasilnya adalah $70,13 \%$. Sedangkan siswa yang masih tidak aktif dalam proses pembelajaran hasilnya adalah $30,20 \%$.

Hasil tersebut diperoleh dari data hasil aktivitas siswa yang merupakan rata-rata dari kriteria-kriteria penilaian, sesuai dengan 3 tahap, yaitu: tahap enaktif, tahap ikonik, dan tahap simbolik.

Tabel 3. Hasil aktivitas siswa siklus I

\begin{tabular}{|c|c|c|c|}
\hline No. & Siklus & Aktivitas Siswa & Persentase \\
\hline 1. & I & $\begin{array}{ll}\text { 1. } & \text { Tahap enaktif } \\
\text { 2. Tahap ikonik } \\
\text { 3. Tahap simbolik }\end{array}$ & $\begin{array}{l}75,00 \% \\
70,52 \% \\
64,89 \%\end{array}$ \\
\hline \multicolumn{3}{|c|}{ Rata-rata Aktivitas siswa } & $70,13 \%$ \\
\hline
\end{tabular}

Berdasarkan hasil pada tabel di atas yang diperoleh dari rata-rata pelaksanaan observasi dapat diketahui bahwa aktivitas siswa dalam proses pembelajaran masih belum meningkat. Karena, hasil yang diperoleh belum mencapai kriteria keberhasilan yang sudah ditentukan oleh peneliti, yaitu 78,00\%.

Gambaran hasil proses pembelajaran pada siklus I yang lebih jelas dapat dilihat pada diagram di bawah ini. 


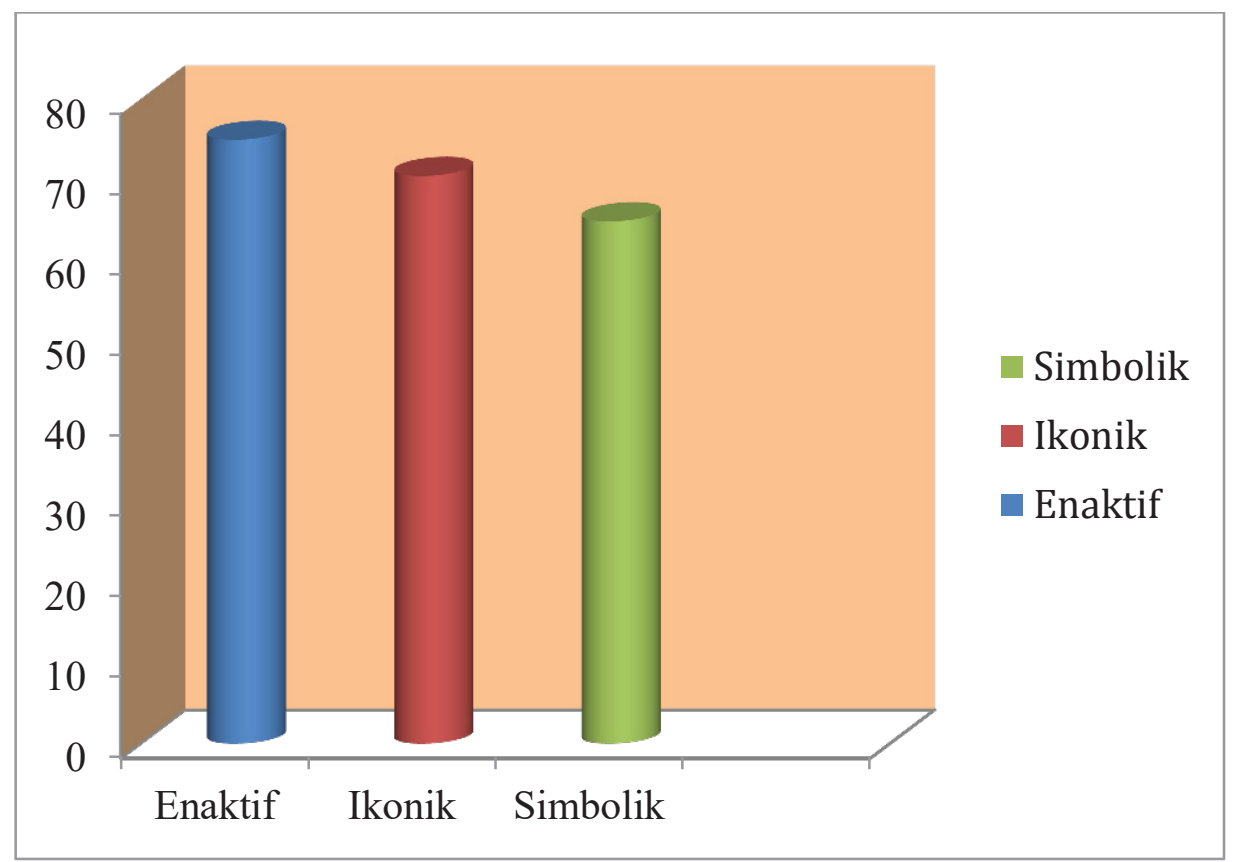

Gambar 1. Hasil aktivitas siswa siklus I

Diagram di atas menunjukkan proses pembelajaran pada siklus I masih kurang sesuai dengan yang direncanakan. Karena, persentase keberhasilan pembelajaran masih rendah. Proses pembelajaran pada siklus I ini terdapat temuan-temuan yaitu sebagai berikut: 1) Siswa belum terbiasa menggunakan benda-benda di sekitar pada saat proses pembelajaran sesuai metode. 2) Siswa masih kurang berani untuk memberikan pertanyaan atau jawaban saat proses pembelajaran. 3) Proses pembelajaran yang dilaksanakan oleh guru terlalu cepat, sehingga siswa belum paham mengerjakan apa yang guru rencanakan. Karena, guru belum membuka pemikiran dan aktivitas siswa belum maksimal. 4) Pada siklus I dilakukan dua kali pertemuan. Karena, meningkatkan aktivitas siswa tidak dapat diselesaikan hanya dengan satu kali pertemuan saja, maka peneliti melanjutkan pertemuan berikutnya.

3. Observasi / Evaluasi

Proses pembelajaran pada siklus I terdapat beberapa temuan yaitu sebagai berikut: 1) Siswa belum terbiasa menggunakan benda-benda di sekitar pada saat proses pembelajaran sesuai metode. 2) Siswa masih kurang berani untuk memberikan pertanyaan atau jawaban saat proses pembelajaran. 3) Proses pembelajaran yang dilaksanakan oleh guru terlalu cepat, sehingga siswa belum paham mengerjakan apa yang guru rencanakan. Karena, guru belum membuka pemikiran dan aktivitas siswa belum maksimal. 4) Pada siklus I dilakukan dua kali pertemuan. Karena, meningkatkan aktivitas 
siswa tidak dapat diselesaikan hanya dengan satu kali pertemuan saja, maka peneliti melanjutkan pertemuan berikutnya.

Hasil yang diperoleh dari proses pembelajaran siklus I melalui observasi aktivitas siswa mencapai 70,13\% dalam 3 tahap, yaitu (a) tahap enaktif, menunjukkan jaring-jaring benda konkret 75,00\%, (b) tahap ikonik, menggambar jaring-jaring kubus dan balok $70,52 \%$, (c) tahap simbolik, menulis jumlah jaring-jaring kubus dan balok 64,89\%.

4. Refleksi

Keberhasilan dan kegagalan yang terjadi pada siklus I adalah sebagai berikut: 1) Guru terlalu cepat dalam menyampaikan materi. 2) Siswa belum memahami metode yang guru gunakan. 3) Mental siswa masih kurang, sehingga beberapa kelompok kurang mampu mempresentasikan hasil kerja kelompoknya di depan kelas. 4) Kurang bekerja sama dalam kelompok.

Kegagalan yang diketahui pada siklus I ini maka peneliti memperbaiki pada saat siklus kedua dibuat perencanaan sebagai berikut: 1) Guru menyampaikan materi dengan berinteraksi pada siswa dengan waktu yang tepat agar mudah dipahami siswa. 2) Membimbing dan melatih mental setiap siswa dan setiap kelompok dengan intensif. 3) Menjelaskan metode yang guru gunakan dalam pembelajaran. 4) Menerapkan metode yang sesuai karakter siswa, dan menerapkan dalam 3 tahap. 5) Menampilkan bendabenda konkret yang mudah siswa mengerti.

\section{Hasil Tindakan Siklus II}

1. Perencanaan

Pada tahap perencanaan pada siklus II ini, peneliti telah membuat RPP yang dilaksanakan dengan menerapkan multi representasi. Peneliti membuat lembar kerja siswa, evaluasi hasil belajar, menentukan kriteria keberhasilan, dan membuat evaluasi proses pembelajaran yang dilakukan oleh observer.

2. Pelaksanaan

Pelaksanaan penelitian ini terdiri dari langkah-langkah sebagai berikut: 1) Memperagakan benda-benda konkret yang berbentuk kubus dan balok. 2) Membentuk siswa menjadi 7 kelompok. 3) Siswa menggambar beberapa bentuk jaring-jaring. 4) Setiap kelompok menyusun bangun datar persegi dan persegi panjang menjadi jaringjaring kubus dan balok. 5) Setiap kelompok menyusun bersama-sama di depan kelas. 6) Memberi penghargaan pada setiap pekerjaan siswa. 7) Guru melakukan evaluasi terhadap hasil belajar siswa, setelah siswa melakukan berbagai aktivitas dalam proses 
pembelajaran. Selain itu observer melakukan observasi apakah sudah sesuai atau tidak pelaksanaan dengan rencana yang dibuat dalam RPP.

\section{SIMPULAN}

Berdasarkan hasil analisis data yang telah diuraikan dalam laporan penelitian ini, maka dapat ditarik kesimpulan sebagai berikut:

1. Proses pembelajaran matematika yang monoton yang membuat siswa bosan. Karena, metode, media, atau model yang guru gunakan selama ini tidak dapat menarik minat, dan perhatian siswa. Sehingga, siswa sibuk sendiri dan tidak berinteraksi dengan guru yang menyampaikan materi pelajaran.

2. Belajar matematika yang hakikatnya adalah belajar tentang hubungan-hubungan antara konsep-konsep pada materi matematika, akan membuat siswa mudah memahami materi pelajaran. Maka, dengan belajar konsep-konsep materi matematika dengan secara langsung membuat siswa mudah mengerti.

3. Kegiatan-kegiatan yang siswa lakukan dengan 3 tahap, yaitu enaktif, ikonik, dan simbolik membuat siswa beraktivitas dengan maksimal.

4. Dengan beraktivitas, siswa dapat mudah mengetahui jawaban tentang apa, bagaimana, dan kenapa yang dilakukan dalam suatu hal, khususnya siswa dapat mengetahui tentang materi yang dipelajari dengan mudah.

5. Aktivitas siswa terhadap proses pembelajaran matematika sangat baik dengan menerapkan multi representasi.

6. Dalam proses pembelajaran menggunakan benda-benda konkret yang ada di lingkungan sekitar membuat siswa mudah memahami materi.

\section{DAFTAR PUSTAKA}

Admin. (2011) Artikel pendidikan Matematika. Pmat.uad.ac.id/

Arikunto, S. (2006). Penelitian Tindakan Kelas. Jakarta: Bumi Aksara.

Anton Antonius. (2011). Analisis Pembelajaran Kewirausahaan. Pontianak: Universitas Tanjung Pura.

Bruner dalam http//mathematicwandy.com diakses tanggal 8 April 2015

Badan Pengembangan Sumber Daya Manusia pendidikan dan Penjamin Mutu Pendidikan (BPSDMPPMP). (2012). Teori Belajar dalam Pembelajaran Matematika. Jakarta: Pusat pengembangan profesi penelitian. 
Hutagaol Kartinji. (2009). Strategi Multi Representasi, repositori. upi.edu/ operator/upload/d.Mtk.0706088-chapter 2.pdt (online dibuka 28, Januari 2013).

Teori Belajar-Bruner. Hmtl (Online dibuka 27, Januari 2013).

Mubarak, Nadif. (2012). Aktivitas Belajar.id.scribd.com/doc/Pengertian Aktivitas-belajar (Online dibuka 29, April 2013).

Yusfy. (2011). Pengertian Aktivitas belajar. Halaman utama. Shvoong. Ilmu Sosial. Pendidikan. Pengertian Aktivitas belajar (online dibuka 30. April 2013). 